\title{
A LIVRE INICIATIVA E A AUTONOMIA PRIVADA NO DIREITO TRIBUTÁRIO: ELISÃO E EVASÃO FISCAIS E PLANEJAMENTO TRIBUTÁRIO VERSUS ART. 116, PARÁGRAFO ÚNICO, DO CTN
}

\author{
A FREE ENTERPRISE AND AUTONOMY PRIVATE IN TAX LAW: TAX \\ EVASION AND AVOIDANCE AND TAX PLANNING VERSUS ART. 116, \\ PARAGRAPH, OF CTN
}

${ }^{1}$ Rita Diniz Caminhoto

\begin{abstract}
RESUMO
Os princípios da livre iniciativa e da autonomia privada são basilares da República Federativa do Brasil. Por meio da autonomia privada, o Estado concede ao ser humano em sociedade, o poder de agir conforme sua vontade, desde que de acordo com os preceitos da lei. Ele pode contratar, enfim, realizar todos os atos e negócios jurídicos permitidos em lei. O contribuinte tem o direito de buscar formas menos onerosas para efetuar suas atividades econômicas, como a adoção do recurso denominado planejamento tributário para alcançar o lucro e reduzir a carga tributária. Este trabalho tem como objetivo estudar a elisão e a evasão fiscais, a simulação, a dissimulação, a fraude à lei, o abuso de direito e de forma, para poder interpretar se dado planejamento tributário no caso concreto, é lícito ou não, compreender as doutrinas business purpose doctrine, substance over form doctrine e step transaction doctrine e verificar qual posição foi adotada pelo ordenamento jurídico brasileiro, sobre a classificação do planejamento tributário em lícito ou ilícito e expõe as opiniões de diversos autores sobre qual delas deva ser aplicada para o entendimento do disposto no parágrafo único do art. 116, do CTN. Como métodos adotados para a confecção deste trabalho, foram empregados o dedutivo, o sistêmico e o axiológico, com uso de pesquisa bibliográfica, constando a doutrina jurídica, artigos científicos, jurisprudência e o ordenamento jurídico brasileiro, como a Constituição Federal de 1988, o Código Tributário Nacional. A problemática e a justificativa deste artigo científico refere-se às divergências quanto a interpretação do parágrafo único do art. 116, do CTN, em relação às figuras jurídicas adotadas no planejamento tributário pelas empresas, em nome dos princípios da livre iniciativa e da autonomia privada, se tal norma é considerada antielisiva ou antievasiva. Busca entender as figuras da elisão e evasão fiscais, a simulação e dissimulação, o abuso de forma e de direito. Portanto, esses serão os assuntos abordados no presente trabalho, de forma a contextualizá-los no direito tributário e entender a polêmica do planejamento tributário.
\end{abstract}

Palavras-chave: Autonomia privada, Elisão fiscal, Evasão fiscal, Livre iniciativa, Planejamento tributário

\footnotetext{
${ }^{1}$ Especialista em Direito Aplicado pela Escola da Magistratura do Paraná, núcleo Londrina - PR, (Brasil). E-mail: ritadinizcaminhoto@hotmail.com
} 


\begin{abstract}
The principles of free enterprise and private autonomy are basic the Federative Republic of Brazil. Through the private autonomy, the State grants the human being in society, the power to act at will, since according to the precepts of the law. He can hire, finally, perform all acts and legal transactions allowed by law. The taxpayer has the right to seek less expensive ways to make their economic activities, such as the adoption of so-called resource tax planning to achieve profit and reduce the tax burden. This work aims to study the avoidance and tax evasion, simulation, dissimulation, fraud to the law, abuse of law and order, to be able to play if given tax planning in this case it is lawful or not, understand the doctrines business purpose doctrine, substance over form doctrine and step transaction doctrine and find what position was adopted by the Brazilian legal system, on the classification of tax planning in licit or illicit, and provides the views of various authors about which of them should be applied to the understanding of the provisions of the sole paragraph of article 116, of CTN. As methods adopted for the preparation of this paper, deductive employees, systems and axiological, using literature, stating the legal doctrine, scientific articles, case law and the Brazilian legal system, as the Federal Constitution of 1988, the Code National Tax. The problems and the justification of this scientific article refers to differences in interpretation of the sole paragraph of art. 116, from CTN, in relation to legal forms adopted in tax planning by companies on behalf of the principles of free enterprise and private initiative, whether such a standard is considered not avoidance or not evasion. Seeks to understand the figures of tax avoidance and tax evasion, simulation and concealment, abuse of form and law. So, these are the issues addressed in this work in order to put into perspective the tax law and understand the controversy of tax planning.
\end{abstract}

Keywords/Palabras-claves/Mots-clés: Private autonomy, Tax avoidance, Tax evasion, Free initiative, Tax planning 


\section{INTRODUÇÃO}

O princípio da livre iniciativa decorre do sobreprincípio liberdade, considerado fundamental à expressão do ser humano. Do mesmo modo, o princípio da autonomia privada é fundamental para que o ser humano possa se expressar e se manifestar em todas as esferas de sua existência. São, por conseguinte, princípios constitucionais que alicerçam a República Federativa do Brasil. No que tange à economia, a livre iniciativa é imprescindível no Estado Democrático de Direito para que possa cumprir com o primado da ordem econômica brasileira. Da livre iniciativa decorre o princípio da liberdade de iniciativa, que tem como escopo, a conquista da justiça social.

Destarte, o contribuinte tem o direito de buscar formas menos onerosas para empreender. Com isso, ele tem buscado recursos que melhorem sua gestão econômica e tributária, como o planejamento tributário, para alcançar o lucro e reduzir a carga tributária.

Os métodos empregados para a elaboração deste artigo científico foram o dedutivo, o sistêmico e o axiológico, por meio de pesquisa bibliográfica, constando a doutrina jurídica, artigos científicos e o ordenamento jurídico brasileiro, como a Constituição Federal de 1988, o Código Tributário Nacional e o Código Civil de 2002.

O presente trabalho tem como objetivo estudar os institutos jurídicos envolvidos no planejamento tributário, tais como, a elisão e a evasão fiscais, a simulação, a dissimulação, a fraude à lei, o abuso de direito e de forma, a fim de poder classificar o planejamento tributário no caso concreto, em lícito ou ilícito e permitir que a Administração Pública aplique medidas cabíveis para evitar a evasão fiscal. Outrossim, busca compreender as doutrinas importadas dos Estados Unidos, a "business purpose doctrine", a "substance over form doctrine" e a "step transaction doctrine quanto à posição adotada no Brasil, a respeito da licitude ou não do planejamento tributário no caso concreto, bem como compreender qual delas deva ser aplicada para o entendimento do disposto no parágrafo único do art. 116, do CTN.

A problemática deste artigo científico refere-se às divergências que se tornaram mais acirradas em decorrência do parágrafo único do art. 116, do CTN, em relação ao planejamento tributário adotado, em especial pelas empresas privadas, que, em nome dos princípios da livre iniciativa e da autonomia privada, têm o poder-dever de adotar métodos mais econômicos para readequarem-se às surpresas do mercado cada vez mais concorrente. Tais planejamentos configuram-se lícitos? Esse parágrafo único do art. 116, do CTN é considerado uma norma antielisiva ou antievasiva? 
Por esse motivo, passar-se-ão ao estudo dos princípios elencados e dos institutos descritos para contextualizá-los no direito tributário.

\section{A ORDEM ECONÔMICA BRASILEIRA NO DIREITO TRIBUTÁRIO: PRINCÍPIOS DA LIVRE INICIATIVA E DA AUTONOMIA PRIVADA}

Os princípios constitucionais "livre iniciativa" e a "autonomia privada" são uns dos pilares da República Federativa do Brasil.

$\mathrm{O}$ art. $5^{\circ}$, inciso XIII, da Constituição Federal preleciona o direito ao livre exercício de qualquer trabalho, ofício ou profissão, desde que se respeitem as qualificações profissionais que a legislação determinar. Percebe-se aí, a inserção implícita do sobreprincípio "liberdade", que é um princípio do princípio, fundamental à manifestação da expressão do ser humano, que, na sua ausência, torna-o apenas um fantoche nas mãos do Estado.

Lobato Gómez (2006, p. 246) aduz: “A primeira, que o princípio constitucional da livre-iniciativa econômica só pode ser concebido como uma concreção de outro princípio constitucional mais geral: o princípio da liberdade."

Da livre iniciativa decorre o princípio da liberdade de iniciativa, que tem como escopo, a conquista da justiça social.

A liberdade de iniciativa econômica abarca a iniciativa privada e a cooperativa e a iniciativa pública. Inconteste afirmar que o sistema capitalista está alicerçado na propriedade privada, na livre iniciativa e no livre mercado.

Pela análise do mercado, no que atine a livre iniciativa e o livre mercado, Rachel Sztajn (2010, p. 11) considera haver duas vertentes: "a liberal, em que a livre iniciativa e livre concorrência são vistas como favorecedoras das eficiências alocativa e produtiva, e a social, que impõe limites à livre iniciativa para privilegiar outros valores."

A propriedade no Estado Democrático de Direito brasileiro, rumo ao Estado Social, apresenta-se como uma interface entre as correntes liberalista-econômica e a socialistacomunista. Ela não é mais um direito absoluto, pois a liberdade se tornou relativa, com limitação baseada no interesse público e social.

Há uma tendência de se defender uma linha social-democrata, que se constitui numa posição intermediária entre as correntes liberalista-econômica e socialistacomunista. Isto é, não há liberdade absoluta; tem-se, contudo, liberdade de iniciativa até o ponto de não prejudicar interesse público e social, mesmo porque, como já foi dito anteriormente, não se trata de um direito ilimitado, absoluto. (ZANOTI, Luiz Antonio Ramalho. Empresa na ordem econômica social. Princípios e função social. Curitiba: Juruá, 2009, p. 86) 
Inconteste salientar que havendo limitação à liberdade, com a incidência do Estado nas relações privadas, de maneira a restringi-las e regulá-las, não se pode configurar uma modalidade intermediária entre as correntes opostas, como a liberalista-econômica e a socialista-comunista: o que se configura, na verdade, é a corrente socialista-comunista.

O princípio da livre iniciativa é desdobrado nos princípios da liberdade de empresa e da livre concorrência, guias da ordem econômica brasileira.

O livre empreendimento é disposto no art. 170, parágrafo único, da Constituição Federal de 1988. As pessoas físicas ou jurídicas, nacionais ou estrangeiros, têm o direito de empreender, em outras palavras, de praticar atividade econômica no Brasil, independentemente da autorização de órgãos públicos, exceto nos casos previstos em lei.

Em contraponto, a Constituição Federal brasileira determina que o Estado exerça intervenções no mercado, como agente normativo e regulador, pelas funções de fiscalização, planejamento e incentivo ao setor privado, como limites da livre iniciativa.

Portanto, hão de ser respeitados, na construção teórica do princípio da livreiniciativa: os princípios de igualdade, formal e substancial; de justiça, seja comutativa, seja social ou distributiva; a dignidade da pessoa humana, que inspira todo o edifício constitucional; a solidariedade social, a função social da propriedade e o desenvolvimento sustentável; a defesa dos consumidores e do meio ambiente; ou, enfim, o respeito dos direitos sociais citados no art. $6^{\circ}$ do texto constitucional. (GÓMEZ, J. Miguel Lobato. Livre-iniciativa, autonomia privada e liberdade de contratar. In: NALIN, Paulo Roberto Ribeiro (coord.). Contrato \& Sociedade: A autonomia privada na legalidade constitucional. v. II. Curitiba: Juruá, 2006, p. 246)

Destarte, conforme a doutrina preleciona, o princípio da livre iniciativa permite que o sujeito de direitos possa praticar sua atividade econômica de forma livre. Contudo, deve cumprir com a função social, o que configura uma liberdade dita equilibrada, visando alcançar a justiça social.

A autonomia privada, outro princípio fundamental no Estado Democrático de Direito é uma norma de comportamento conferido ao homem pelo ordenamento jurídico para realizar relações patrimoniais.

Autonomia significa, etimologicamente, dar-se a si próprio normas de comportamento, auto-regular-se [sic]. Por conseguinte, o princípio da autonomia privada é uma expressão sintética que serve para ressaltar que o ordenamento jurídico reconhece aos particulares um amplo poder de autodeterminação da pessoa e de autoregulação [sic] de suas relações patrimoniais. (GÓMEZ, J. Miguel Lobato. Livreiniciativa, autonomia privada e liberdade de contratar. In: NALIN, Paulo (coord.). Contrato \& Sociedade. A autonomia privada na legalidade constitucional. Curitiba: Juruá, 2006, p. 252) 
O princípio da autonomia da vontade diz respeito à liberdade, que pode estabelecer uma relação jurídica contratual com alguém, conforme seus interesses. A moralidade das condutas é aferida por ela.

“A autonomia privada é princípio fundamental de todo e qualquer sistema jurídico que se baseia na lógica da relevância da vontade humana ou no poder de autodeterminação da pessoa." (NALIN, Paulo. A autonomia privada na legalidade constitucional. In: NALIN, Paulo (coord.). Contrato \& Sociedade. A autonomia privada na legalidade constitucional. Curitiba: Juruá, 2006, p. 23)

Um direito ou uma obrigação deriva do exercício do poder de declaração da vontade, que pode ser unilateral ou em concurso de vontades.

"Note-se apenas, que a autonomia privada não se confunde com a autonomia da vontade, posto que, enquanto esta última apresenta uma conotação subjetiva, aquela é o poder dos particulares de normatizar as relações jurídicas das quais participam.” (TORRES, Andreza Cristina Baggio. Direito civil-constitucional: a função social do contrato e a boa-fé objetiva como limites à autonomia privada. In: NALIN, Paulo (coord.). Contrato \& Sociedade. A autonomia privada na legalidade constitucional. Curitiba: Juruá, 2006, p. 49)

De acordo com Orlando Gomes (2002, p. 24), o princípio da autonomia da vontade particulariza-se no Direito Contratual na liberdade de contratar. Significa o poder dos indivíduos de suscitar, mediante declaração de vontade, efeitos reconhecidos e tutelados pela ordem jurídica.

Com as transformações ocorridas devido ao desenvolvimento do Estado Social e a sociedade de massas, acrescida com a pressão exercida pela população que clama por uma justiça distributiva, o Estado, sentindo que não mais poderia suportar essa liberdade contratual desenfreada, estabelece o dirigismo contratual, cuja ordem pública, as quais não se poderia contrariar sobre o fundamento de se aplicar às relações contratuais o princípio da autonomia da vontade, a exemplo o Código de Defesa do Consumidor e a Lei do Inquilinato. (DE PAULA, Lucimar. A problemática da aplicação do princípio da autonomia privada nas relações contratuais contemporâneas. In: NALIN, Paulo. Contrato \& Sociedade. Princípios de Direito Contratual. v. I, Curitiba: Juruá, 2008, p. 75)

Submete-se à autonomia da vontade, às normas morais aprovadas pelo ordenamento jurídico, à função social do contrato, à boa-fé objetiva, ao equilíbrio contratual e à lealdade contratual, o dirigismo estatal. 


\begin{abstract}
Em particular, a autonomia da vontade encontra seu primeiro e mais importante limite não só nas normas de caráter impositivo que emanam da ordem pública, mas também nas normas morais aceitas pelo próprio ordenamento jurídico e em outros princípios inspiradores do moderno Direito contratual como a função social do contrato, a lealdade contratual, a probidade, a boa-fé objetiva ou o equilíbrio contratual. (GÓMEZ, J. Miguel Lobato. Livre-iniciativa, autonomia privada e liberdade de contratar. In: NALIN, Paulo (coord.). Contrato \& Sociedade. A autonomia privada na legalidade constitucional. Curitiba: Juruá, 2006, p. 254-255)
\end{abstract}

A autonomia da vontade está alicerçada no Estado Democrático de Direito, e condicionada ao princípio da supremacia da ordem pública.

Uma vez que a autonomia privada e a livre iniciativa estão atreladas, rumo ao desenvolvimento nacional, prelecionados na ordem econômica brasileira, o planejamento tributário é um procedimento empregado pelos empresários e administradores de empresas para reduzir os custos e alcançar maior lucro. Na contramão, o Estado procura encontrar meios para captar mais recursos para suprir os cofres públicos, sob o escopo de alcançar a justiça fiscal e realizar o fim social mais importante, que é o desenvolvimento nacional. Para que não haja perda do erário, os legisladores, por meio do direito tributário, apresentam institutos jurídicos que classificam quais atos e negócios jurídicos são considerados lícitos, e, por conseguinte, podem ser utilizados no planejamento tributário das empresas. À essa altura do presente trabalho, inconteste tecer comentários sobre o planejamento tributário e distinguir essas figuras jurídicas.

\title{
3 PLANEJAMENTO TRIBUTÁRIO: A LINHA TÊNUE DA DISTINÇÃO ENTRE ELISÃO E EVASÃO FISCAL
}

Direito garantido pela Constituição Federal e a Lei nº 6.404/76, em seu artigo 153, cabe ao administrador agir com diligência e cuidado a fim de administrar os negócios da companhia. O planejamento tributário deve ser visto como parte deste cuidado delegado ao administrador, no exercício de suas funções na empresa. Isto porque o legislador, a fim de prover os cofres públicos, sempre elimina as possibilidades de redução da carga tributária.

Por este motivo, o contribuinte deve ficar atento as alterações no ordenamento jurídico para bem administrar seus bens e reduzir os custos, a fim de não praticar evasão fiscal.

"O planejamento tributário é o processo de escolha de ação, não simulada, anterior à ocorrência do fato gerador, visando direta ou indiretamente à economia de tributos.” (CHAVES, 
Francisco Coutinho. Planejamento tributário na prática. Gestão tributária aplicada. 3. ed. São Paulo: Atlas, 2014, p. 5)

Institutos distintos, a elisão e a evasão fiscal, no Brasil sofrem divergências na prática, por parte da Administração Pública e do setor privado, cada um deles antagonicamente conectados: o setor privado, a fim de justificar seus atos e negócios jurídicos como válidos e lícitos para a persecução do seu objetivo maior, ou seja, a economia tributária e o lucro, em contrapartida, a Administração Pública, com sua cultura fiscalista, a fim de satisfazer as necessidades da máquina estatal.

Essas divergências se tornaram mais acirradas em decorrência do parágrafo único do art. 116, do CTN, em relação ao planejamento tributário adotado, em especial pelas empresas privadas, que, para sobreviver, procuram adotar métodos mais econômicos para readequarem- se às surpresas do mercado cada vez mais concorrente. Assim, partem para o planejamento em todos os seus setores, como na gestão de seus negócios, e na economia tributária.

Para a compreensão das divergências antagônicas em relação à elisão e a evasão físcal, bem como o fundamento da livre iniciativa proposto pela ordem econômica brasileira, importante traçar conceitos sobre os princípios ontológicos do direito, como a expressão que preleciona que "tudo que não estiver juridicamente proibido, estará juridicamente permitido", princípio determinante do regime jurídico privado, em detrimento da expressão: "tudo que não estiver juridicamente permitido, estará juridicamente proibido", princípio determinante do sistema normativo público.

Dado que todo princípio é regra que possui núcleos significativos relevantes, ele influencia claramente a formação das cadeias normativas, às quais outorga caráter de unidade relativa, servindo de fator de agregação para outras regras do sistema do direito posto, veremos, no regime jurídico privado, a observância integral da dicção de que "tudo que não estiver juridicamente proibido, estará juridicamente permitido". Esse é o fundamento que autoriza e confirma a liberdade dos particulares na elaboração de atos jurídicos recepcionados pelo sistema jurídico positivo. (CARVALHO, Paulo de Barros. Derivação e positivação no direito tributário. 2. ed. Livro I. São Paulo: Noeses, 2014, p. 76)

Assim, um dos requisitos imprescindíveis para que o ato ou negócio jurídico realizado pelo contribuinte seja considerado lícito é o fato de não ser proibido pelo ordenamento jurídico brasileiro.

"Sendo lícito o ato - pois não se encontra juridicamente proibido, nem tampouco infringe prescrição legal alguma - não pode ele ser desconsiderado pela autoridade administrativa, com o argumento de que implicaria menor carga tributária." (CARVALHO, Paulo 
de Barros. Derivação e positivação no direito tributário. 2. ed. Livro I. São Paulo: Noeses, 2014, p. 77)

Os negócios ou atos jurídicos lícitos são válidos, pois apenas visam a uma reestruturação fiscal, para que haja redução ou até eliminação da carga tributária.

A ordem jurídica é regida por sobreprincípios, tais como, a segurança jurídica, a justiça e a certeza do direito. Este último sobreprincípio preleciona que o direito seja determinado por um devir, um dever ser, o aspecto imperativo deste. Assim, estabelece-se que o fato deve ser de determinada forma, gerando determinada consequência, na hipótese de seu cumprimento ou no caso de seu inadimplemento.

\footnotetext{
III - Observamos, ainda, que nossa Constituição, no louvável propósito de transformar a República Brasileira num Estado Democrático de Direito, submeteu a ação tributária das pessoas políticas a um extenso rol de princípios (federativo, da legalidade, da igualdade, da anterioridade, da segurança jurídica, da reserva de competências etc.), que protegem, ao máximo, os contribuintes, contra eventuais abusos fazendários.

Além disso, são os princípios constitucionais que, por assim dizer, direcionam o teor das leis tributárias e em seus modos de aplicação. (CARRAZZA, Roque

Antonio. Curso de direito constitucional tributário. 26. ed. São Paulo:

Malheiros, 2010, p. 62-63)
}

A segurança jurídica representa a previsibilidade dos direitos e deveres estabelecidos no direito, de maneira que se saiba quais efeitos jurídicos de suas condutas acontecerão.

"Em estreita síntese, o postulado da segurança jurídica consiste na possibilidade pela qual os destinatários de normas jurídicas tenham conhecimento dos direitos e deveres estabelecidos no direito, podendo, assim, prever os efeitos jurídicos de suas condutas." (JARDIM, Eduardo Marcial Ferreira. Dicionário de direito tributário. São Paulo: Noeses, 2011, p. $85)$.

Quanto ao sobreprincípio justiça, de acordo com Eduardo Marcial Ferreira Jardim (2011, p. 86), em sentido formal corresponde à conformidade dos fatos ao direito. No sentido ético e moral, pressupõe a razão, a equidade, que é o objetivo maior do direito.

O contribuinte terá obrigação de pagar tributo se tal ato praticado adequar-se perfeitamente hipótese da regra-matriz de incidência tributária, em acato aos princípios da tipicidade fechada e da estrita legalidade.

A tipicidade tributária significa a exata adequação do fato à norma, e, por isso mesmo, o surgimento da obrigação se condicionará ao evento da subsunção, que é a plena correspondência entre o fato jurídico tributário e a hipótese de incidência, fazendo surgir a obrigação correspondente, nos exatos termos previstos em lei. Não se verificando o perfeito quadramento do fato à norma, inexistirá obrigação tributária. Nesse percurso, ou ocorre a subsunção do fato à regra, ou não ocorre, afastando-se terceira possibilidade. Perfaz-se aqui a eficácia da lei lógica do terceiro excluído. Por outro lado, ocorrido o fato, a relação obrigacional que nasce há de ser 
exatamente aquela estipulada no consequente normativo. (CARVALHO, Paulo de

Barros. Curso de direito tributário. 25. ed. São Paulo: Saraiva, 2013, p. 478)

A organização preventiva dos negócios jurídicos é permitido uma vez que a livre iniciativa está prelecionada na ordem econômica, desde que esses atos ou negócios jurídicos não se enquadrem nas normas jurídicas tributárias. Se não se enquadrar na hipótese da regramatriz de incidência tributária, em razão do princípio da estrita legalidade e da tipicidade fechada, este não será considerado inválido e ilícito. Eles apenas teria resultados econômicos semelhantes aos decorrentes da concretização dos fatos que ensejariam o nascimento de débitos tributários. Tanto é assim que uma empresa pode mudar de estrutura societária de forma legal, sem que isso afete o disposto no direito tributário.

As condutas abusivas são objeto das políticas fiscais das legislações da maioria dos países, vez que estas obstam que o Estado recolha tributos suficientes para seu funcionamento. Há, por conseguinte, uma luta entre o poder público e o privado, no sentido de preservar a igualdade (de acordo com Roque Antonio Carrazza (2010, p. 86), "a lei tributária deve ser igual para todos e a todos deve ser aplicada com igualdade"), a capacidade contributiva (primeira parte do $\S 1^{\circ}$, do art. 145, da $\mathrm{CF}$ ), a concorrência fiscal e solidariedade, em detrimento da segurança jurídica, da liberdade e da legalidade.

\begin{abstract}
Admitir o combate ao abuso é uma opção de política fiscal já aceita pela maioria dos países, porém, para ser aplicado é precisa uma autorização legislativa, não podendo simplesmente resultar de um ativismo administrativo ou jurisprudencial. (QUEIROZ, Mary Elbe. O planejamento tributário: procedimentos lícitos, o abuso, a fraude e a simulação. In: GRUPENMACHER; CAVALCANTE; RIBEIRO; QUEIROZ (org.) Novos horizontes da tributação: um diálogo luso-brasileiro. Cadernos IDEFF Internacional. Coimbra: Almedina, 2012, p. 335)
\end{abstract}

O direito privado se entrelaça ao direito tributário quando fatos que ensejam tributação por parte do legislador são juridicizados ao empregar tipos estruturais relacionados a formas e atos de direito privado. Incidirá a tributação somente se o particular adotar procedimento para a concretização do negócio jurídico correspondente à forma prevista na norma. Caso contrário, não será o mesmo negócio jurídico, mesmo que seus efeitos econômicos sejam iguais ao disposto na norma, porque não haverá enquadramento do fato à norma.

6. Os elementos categoriais (causa) e existenciais dos negócios jurídicos são relevantes para a qualificação de fatos jurídicos, enquanto os requisitos que condicionam a validade (legitimidade ou validade em sentido estrito) dos negócios jurídicos não interferem na qualificação do fato jurídico. (NACNAUGHTON, Charles William. Elisão e norma antielisiva. Completabilidade e sistema tributário. São Paulo: Noeses, 2014, p. 497-498) 
Sendo lícito o procedimento adotado pelo particular, a fim de operacionalizar da melhor forma suas atividades negociais, não há que se falar em desconsideração por parte da autoridade administrativa tributária, em razão do princípio da legalidade tributária e da tipicidade fechada.

Vale distinguir elisão, que é denominada evasão lícita por parte de Alfredo Augusto Becker, de fraude. Esta distinção baseia-se no instante em que os atos foram praticados pelo particular, no que tange à ocorrência do fato gerador da obrigação tributária, em outras palavras, haverá elisão se esses atos forem praticados antes da ocorrência do fato gerador da obrigação tributária e será fraude se ocorrerem depois.

\begin{abstract}
10. A elisão tributária pressupõe a comparação entre uma carga fiscal projetada e uma carga fiscal efetiva - sendo a carga fiscal efetiva inferior à carga fiscal potencial - pelo contribuinte a partir um ato que possibilite (i) a não subsunção à hipótese de incidência da regra-matriz de incidência tributária, (ii) aplicabilidade de subcritério da regra-matriz de incidência que importe a imposição da carga fiscal atingida ou (iii) a aplicação de uma norma de benefício fiscal. (NACNAUGHTON, Charles William. Elisão e norma antielisiva. Completabilidade e sistema tributário. São Paulo: Noeses, 2014, p. 498)
\end{abstract}

É lícita a elisão, enquanto que a fraude é ilícita, uma vez que é feita a fim de violar a regra jurídica ou desprezar a eficácia jurídica, condicionada à nulidade, à anulabilidade ou ineficácia da estrutura fraudulenta e à inexistência.

\begin{abstract}
11. O ato por meio do qual se faz a elisão tributária pode importar a escolha menos onerosa, fiscalmente, entre duas possíveis para se atingir um fim ou pode ser efetivado com fins exclusivos ou preponderantes para se obter a economia fiscal elisiva. (NACNAUGHTON, Charles William. Elisão e norma antielisiva. Completabilidade e sistema tributário. São Paulo: Noeses, 2014, p. 498)
\end{abstract}

Assim, mesmo que os meios empregados para a realização deste procedimento negocial forem lícitos, se feitos após a ocorrência do fato gerador da obrigação tributária, o Fisco poderá objetar tal negócio, para proteção de seu direito adquirido ao recebimento do tributo, uma vez que pode ter sido feito com a intenção de evitar a realização do fato gerador da obrigação tributária ou mascarar tal fato imponível sob outra figura tipificada na lei.

De acordo com Charles William Nacnaughton (2014, p. 499), "a elisão tributária é um suporte fático do direito de recolher o tributo devido em conformidade com a lei. A elisão, em si, não interessa, integralmente, à norma tributária, e o ato elisivo não configura fraude à lei nem em abuso de direito."

As legislações da maioria dos países têm caminhado na tendência de capturar as condutas abusivas, devido à tendência mundial ao Estado Social, que se apresenta com um intenso dirigismo estatal em todas as esferas de poder. É fato que Estados Sociais exigem altas 
cargas tributárias aos contribuintes para a manutenção de suas metas. Com isso, verificam-se disputas entre valores fundamentais, tais como a legalidade, a liberdade e a segurança jurídica, de um lado e em contraponto, a capacidade contributiva, a igualdade, a solidariedade e a concorrência fiscal.

\footnotetext{
Admitir o combate ao abuso é uma opção de política fiscal já aceita pela maioria dos países, porém, para ser aplicado é precisa uma autorização legislativa, não podendo simplesmente resultar de um ativismo administrativo ou jurisprudencial. (QUEIROZ, Mary Elbe. O planejamento tributário: procedimentos lícitos, o abuso, a fraude e a simulação. In: GRUPENMACHER; CAVALCANTE; RIBEIRO; QUEIROZ (org.) Novos horizontes da tributação: um diálogo luso-brasileiro. Cadernos IDEFF Internacional. Coimbra: Almedina, 2012, p. 335)
}

As infrações podem ser classificadas quanto ao critério de participação subjetiva do agente na descrição hipotética da norma em infrações objetivas e subjetivas. As primeiras prescinde o elemento volitivo do agente do ilícito, enquanto as subjetivas, é imprescindível o dolo ou a culpa do agente na descrição hipotética da norma.

"Em linhas gerais, a configuração da infração objetiva independe da culpa ou do dolo, sendo imputada quando comprovada a presença de três requisitos: a) conduta; b) resultado e c) nexo de causalidade entre conduta e resultado." (PADILHA, Maria Ângela Lopes Paulino. As sanções no direito tributário. São Paulo: Noeses, 2015, p. 41)

Para a mesma autora (2015, p. 41), quanto à infração subjetiva, o elemento volitivo é configurado quando verificados os pressupostos conduta, resultado, nexo de causalidade entre conduta e resultado, dolo ou culpa.

Neste caso, compete à autoridade administrativa provar o dolo ou a culpa, em qualquer das três modalidades: imperícia, negligência ou imprudência, que ateste a existência do nexo causal da participação do agente e o resultado material descrito no enunciado descritivo do ilícito na norma. Portanto, faz-se necessária as provas para comprovar as infrações subjetivas, não sendo admitida a presunção.

É fato que no ordenamento jurídico brasileiro, figuras delituosas ou criminosas necessitam de produção de provas por parte da autoridade administrativa para serem configuradas, como por exemplo, a figura da evasão. À autoridade administrativa cabe o ônus da prova, pois quem acusa deve provar, pois ninguém pode ser acusado sem prova, a não ser nos casos em que as presunções legais são admitidas, caso em que a inversão do ônus probatório é cabível ao contribuinte. Conforme aduz Elbe Mary Queiroz (2012, p. 361), essas máximas estão insertas nos princípios constitucionais da legalidade, do devido processo legal, do contraditório e da ampla defesa. 
As empresas têm o direito de perseguir o lucro e escolher livremente qual ato ou negócio jurídico adotará para isso. Sendo lícitos, permitidos, esses objetivos empresariais que carreiem efetiva produção e circulação e riquezas resultarão uma economia legítima. Melhor explicando: se houver dois ou mais meios de se implementar um negócio válido, será lícito e recomendável, até, que a empresa escolha o menos oneroso em termos tributários.

O ato elisivo ou a norma elisiva, como fruto de uma constatação analógica, só surge no momento em que se aproximam duas situações. Quando em plano abstrato, a análise comparativa independe da concreção do fenômeno em interpretação, o que se mostra efetivo somente para os eventos futuros. (CARVALHO, Paulo de Barros. Derivação e positivação no direito tributário. 2. ed. Livro I. São Paulo: Noeses, 2014, p. 87-88)

A simulação é uma maneira de agir do contribuinte que revela uma inadequação ou inequivalência entre a forma jurídica que foi demonstrado o negócio jurídico e sua verdadeira substância ou natureza do fato gerador efetivamente realizado. Essa conduta aparentemente é conforme uma norma, e perfeita e válida conforme o direito privado, mas oculta o real fato sobre o qual é incidente outra norma de tributação, que é mais gravosa. Isso revela a intenção do contribuinte em burlar o Fisco. Trata-se de fraude fiscal ou infração à lei tributária, assim como a dissimulação.

Nas palavras de Paulo de Barros Carvalho (2014, p. 80): “A simulação é, em síntese, uma declaração enganosa da vontade, visando a produzir efeito diverso daquele que a declaração real da vontade acarretaria."

Mas se houver simulação, a fim de se obter vantagem de forma ilícita, quanto a redução da carga tributária imposta ao contribuinte, esta certamente garantirá direito do Fisco descaracterizar o negócio, pois o ato simulado deve ser requalificado pela autoridade administrativa.

O direito privado, em seu art. 167, do Código Civil, preleciona a nulidade do negócio jurídico simulado, permanecendo somente o negócio jurídico dissimulado se sua substância e forma forem válidas.

No direito tributário, aplica-se o direito privado, no que tange a simulação, para configurarem tais atos que mascarem a ocorrência de fato jurídico tributário, de forma a aparentarem ato diverso do que é de fato, para reduzir a incidência do tributo. Destarte, o contribuinte estará reduzindo sua carga tributária de forma ilícita, o que ensejará a desconsideração do negócio jurídico praticado. 
Para que seja admissível a autuação fiscal, desconsiderando o negócio jurídico praticado, não basta que os efeitos econômicos de tal prática sejam semelhantes aos de ato diverso, mas passível de tributação. É imprescindível que tenha havido ilicitude em tal realização, nos exatos termos dos arts. 71,72 e 73, acima transcritos. (CARVALHO, Paulo de Barros. Derivação e positivação no direito tributário. 2. ed. Livro I. São Paulo: Noeses, 2014, p.85)

Um exemplo deste caso é o Acórdão n. CSRF/01.874/94, citado por Paulo de Barros Carvalho (2014, p. 85):

IRPJ - SIMULAÇÃO NA INCORPORAÇÃO - Para que se possa materializar, é indispensável que o ato praticado não pudesse ser realizado, fosse por vedação legal ou por qualquer outra razão. Se não existia impedimento para a realização da incorporação tal como realizada e o ato praticado não é de natureza diversa daquela que de fato aparenta, não há como qualificar-se a operação de simulada. Os objetivos visados com a prática do ato não interferem na qualificação do ato praticado. Portanto, se o ato praticado era lícito, as eventuais situações contrárias ao fisco devem ser qualificadas como casos de elisão fiscal e não de "evasão ilícita”.

As operações simuladas são as que o contribuinte realiza de maneira a mascarar a transação econômica e jurídica, ocultando a realidade, ou seja, a motivo do ato praticado não condiz com a finalidade a ele imputado por lei e há omissão da verdadeira intenção do contribuinte, ensejando, por conseguinte, a ação do Fisco para dar tratamento tributário ao ato, como dissimulado.

\footnotetext{
A título exemplificativo, isto é o que ocorre na subscrição de participação com ágio seguida de imediata cisão e entrega dos valores monetários referentes ao ágio, que configura verdadeira hipótese de alienação de participação societária. (CARVALHO, Paulo de Barros. Derivação e positivação no direito tributário.2. ed. Livro I. São Paulo: Noeses, 2014, p. 82)
}

Os elementos característicos da simulação são a divergência entre a real vontade das partes e o negócio por elas declarado, o conluio entre as partes e a intenção de lograr o fisco.

A simulação e a dissimulação encontram-se tipificadas no art. 167, do Código Civil, que configura nulidade ao negócio jurídico simulado, enquanto que o negócio dissimulado será válido se for considerado válido na sua substância e forma. Ainda pelo mesmo dispositivo, a lei civil preleciona a existência de simulação em negócio jurídico quando aparentar conferir ou transmitir direitos a pessoas diversas das que realmente se conferem ou transmitem; quando contiverem declaração, confissão, condição ou cláusula não verdadeira; quando os instrumentos particulares forem antedatados ou pós-datados. Vale ressaltar que os efeitos definidos pelos princípios gerais do direito privado nem sempre coincidem com os definidos no direito tributário, conforme o disposto no art. 109, do CTN. As normas tributárias não podem desvirtuar o conteúdo dos institutos de direito privado, mas podem construir sua própria realidade, a partir deles, desde que expressamente os estabeleça. Assim aduz Elbe Mary Queiroz (2012, p. 380): 
Se a lei civil dá o conceito de simulação e prevê o respectivo efeito para fins civis, que é a nulidade do negócio, para que se possa transportar a sua aplicação e considerar os efeitos apenas parcialmente para fins tributários, a lei fiscal deverá expressamente dispor de modo diferente, isto é, a lei tributária deverá prever que a desconsideração de um ato ou negócio somente produzirá efeito para fins fiscais, não se estendendo às demais relações jurídicas decorrentes do ato ou negócio, sejam elas societárias, comerciais, [sic] etc.

Quando uma sociedade é constituída por um determinado sócio que integraliza capital em espécie e outro sócio integralize apenas em ações de outra companhia, e após um curto intervalo de tempo ocorra uma cisão desta empresa, e esta seja desfeita, vindo a restituição do capital a ser realizada de modo inverso ao que foi constituído, a Administração Pública tem considerado tal negócio como uma simulação, e portanto, tem desconsiderado esse tipo de operação, por considerar esse curto espaço de tempo indicativo de negócio jurídico simulado. Isso gera perplexidade, pois o critério exclusivo do tempo, para se investigar e desconsiderar um negócio jurídico e o lançamento de crédito tributário causa uma insegurança jurídica enorme, pois não se pode considerar que tal negócio ultrapassou o limiar de licitude e se tornou caso de abuso, de ilícito ou de simulação, pois, trata-se de elemento muito subjetivo para tal, bem como não consta em nenhuma disposição legal. Isto leva a conclusão de que a simulação e a dissimulação não podem ser critério de rejeição de ato ou negócio abusivo, porque são infrações, violações expressas, cujo ordenamento jurídico preleciona mecanismos adequados, bem como sanções para tal, pois não têm conexão com o planejamento tributário. Segundo Elbe Mary Queiroz (2012, p. 282): "Conclui-se, assim, que a simulação é hipótese própria e independente de ilícito tributário e não se confunde com o abuso colocado neste trabalho, como o ato ou o negócio lícito realizado exclusivamente para fins de obtenção de economia fiscal."

Assim, as figuras simulação e dissimulação não podem ser adotadas como critérios em uma Norma Geral Antiabuso (NGAA), porque não constituem abuso, e sim infrações à lei. Ainda, de acordo com a mesma autora (2012, p. 382):

\footnotetext{
Disso decorre o grande equívoco da Lei Complementar n. ${ }^{\circ}$ 104/2001, ao introduzir o parágrafo único ao artigo 116 do CTN na tentativa de criar uma norma "antielisiva" no Brasil, ou antiabuso, como está sendo apresentado neste trabalho. Por isso, a edição de uma NGAA deve ser defendida como a garantia da certeza de que, se a prática do ato ou negócio não estiver proibida ou vedada pela lei, o comportamento do contribuinte é lícito, pois, está sob a proteção da segurança jurídica, e somente será abusivo quando a lei assim a considerar como tal.
}

Exemplos de simulação pode-se citar o leasing de alto valor, que esconde um negócio de compra e venda, por parte do contribuinte, para que evite uma tributação maior sobre o ganho de capital pelo Imposto de Renda. Trata-se de exemplo de evasão tributária. Outros exemplos de evasão tributária são: a compra e venda quando se busca efeitos de garantia, a locação a longo 
prazo e com alto preço para mascarar uma compra e venda, o leasing para disfarçar uma compra e venda, utilizando-se de despesas que reduzem o resultado da empresa, o pagamento de juros dissimulados.

Há vários procedimentos que podem ser classificados como espécies de elisão, dependendo do caso concreto. Entre eles podem ser citados a reavaliação de bens, a reorganização societária, a constituição ou a cisão de empresas, a doação de bens pelo genitor aos filhos e herdeiros, ainda em vida, ou seja, a denominada adiantamento de legítima, a realização de mútuo no lugar de aumento de capital, a criação de uma holding, a alienação de bem de pequeno valor com isenção de imposto sobre a renda que seja incidente sobre o ganho de capital.

Como mencionado anteriormente, na atualidade, diversos países têm adotado uma conduta fiscalista, em decorrência da adoção do Estado Social, como mencionado em tópico acima. Para tal feito, utilizam-se de figuras jurídicas do direito privado para alcançar atos e negócios para determiná-los como abusivos, sem, contudo, chegarem a ser tipificados como ilícitos, porque não violam normas tributárias. O abuso é o ato do contribuinte macular a capacidade contributiva, a concorrência fiscal e a solidariedade, ressumbrando seus efeitos na justiça fiscal, pelo excesso no exercício da liberdade ou da autonomia privada. Como exemplo de figuras jurídicas adotadas por diversos ordenamentos jurídicos para combater a conduta abusiva, pode-se citar o abuso de forma, abuso de direito, fraude à lei, ato anormal de gestão, propósito negocial, negócio indireto, substância sob a forma, realização de atos complexos e em sequência, entre outros.

\footnotetext{
Uma conduta abusiva é aquela que ultrapassa e se situa na fronteira cinzenta entre o lícito e o ilícito, porém é diferente da infração, da fraude ou da simulação, condutas que são violadoras de disposições expressas de lei. NA seara da simulação e da fraude, adentra-se nas condutas tipificadas como crime, daí porque prevalece a máxima nullun crimen sine lege. (QUEIROZ, Mary Elbe. O planejamento tributário: procedimentos lícitos, o abuso, a fraude e a simulação. In: GRUPENMACHER; CAVALCANTE; RIBEIRO; QUEIROZ (org.) Novos horizontes da tributação: um diálogo luso-brasileiro. Cadernos IDEFF Internacional. Coimbra: Almedina, 2012, p. 365-366)
}

Em matéria de imposição tributária, os princípios da segurança jurídica e da certeza do direito, que são a base da legalidade e da tipicidade tributária, quando se trata de abuso de direito e de fraude à lei, é difícil tratar da figura da desconsideração do negócio jurídico, no que tange a ordem econômica.

O abuso de direito é, para Paulo de Barros Carvalho (2013, p. 479): "uma norma produzida pelo particular, constituída no exercício de competência que excede as atribuições 
jurídicas que o Direito autoriza ao sujeito, identificando-o como incompetente naquela função, ao mesmo tempo que atribui ao ato caráter de ilicitude."

No abuso de direito a forma é inadequada e existe a intenção em prejudicar alguém, enquanto que no abuso de forma, a forma é considerada abusiva quando é inadequada. $\mathrm{O}$ abuso de direito ocorre quando se ultrapassam os limites da proporcionalidade e da razoabilidade quando da prática de negócios jurídicos ou quando se for constituir uma sociedade.

No caso de abuso de direito, se o negócio jurídico não tiver causa, pode ocorrer uma requalificação dos atos praticados pelo contribuinte, de forma acidental, conforme aduz Charles William Nacnaughton (2014, p. 498).

A elisão derivada de abuso de direito deve ser combatida em acato ao princípio daigualdade.

Com o objetivo de tornar menos árduo o trabalho da autoridade fiscal, do julgador e do contribuinte, em saber exatamente quando um determinado comportamento deixa de ser lícito e passa a configurar abuso de forma ou abuso de direito, propõe-se o critério geral de se colocar na lei a figura do abuso, de acordo com o critério do propósito negocial que for fixados na NGAA. (QUEIROZ, Mary Elbe. $O$ planejamento tributário: procedimentos lícitos, o abuso, a fraude e a simulação. In: GRUPENMACHER; CAVALCANTE; RIBEIRO; QUEIROZ (org.) Novos horizontes da tributação: um diálogo luso-brasileiro. Cadernos IDEFF Internacional. Coimbra: Almedina, 2012, p. 384-385)

Já, a fraude à lei é aquela produção de norma que é ilícita, mas que se apresenta aparentemente como ato jurídico lícito, para que o contribuinte possa fugir da incidência normativa tributária.

\begin{abstract}
A localização de um ou outro ilícito exige, como requisito essencial, norma válida no sistema, que, em termos objetivos, fundamenta a figura da ilicitude no Direito. A partir do enunciado normativo válido é que o exegeta vai encontrar substrato para depreender desrespeito aos princípios constitucionais de (ii) segurança jurídica, (iii) certeza de direito, (iv) estrita legalidade e (v) tipicidade, em afronta direta à estrutura de repartição de competências tributárias realizada pela Constituição. Estão nesses elementos a figura do ilícito do abuso de direito e da fraude à lei. (CARVALHO, Paulo de Barros. Curso de direito tributário. 25. ed. São Paulo: Saraiva, 2013, p. 479)
\end{abstract}

Nas palavras de Charles William Nacnaughton (2014, p. 498): “A fraude à lei enseja requalificação se o contribuinte aplica norma indevida para fraudar norma aplicável, mas não enseja requalificação por ausência de subsunção do fato à norma".

Após a explanação sobre elisão e evasão fiscais, simulação, dissimulação, fraude à lei, abuso de forma e de direito, faz-se mister adentrar na questão da legitimidade do planejamento tributário e a polêmica sobre o significado do parágrafo único, do art. 116, do CTN. 


\section{PLANEJAMENTO TRIBUTÁRIO VERSUS ART. 116, PARÁGRAFO ÚNICO, DO CTN}

Devido à excessiva carga tributária imposta pelo Estado brasileiro, a injustiça do sistema tributário, a má distribuição da carga tributária, principalmente para aqueles que agem dentro da lei, a incorreta e ineficaz aplicação dos recursos coletados, os desvios e corrupção dos poderes públicos, a concorrência desleal, e a falta de retorno do Estado quanto à prestação de seus serviços, os contribuintes no exercício de suas atividades econômicas procuram meios lícitos para minimizar seus efeitos. Para isso, empregam o planejamento empresarial e tributário.

Em contraponto, o Estado, munindo-se da isonomia e justiça fiscal, objetivando alcançar os fins a que se destina, como, a redistribuição de renda, o fomento da solidariedade, e da igualdade, pela capacidade contributiva, cada vez mais procura instrumentar-se a fim de evitar a diminuição de suas receitas tributárias, por meio de novas normas, com hipóteses de incidência tributária mais aptas a exigir recursos dos contribuintes, por meio de aumento de alíquotas, criação de novas contribuições, combate à sonegação, limitações de despesas e deduções, e criando instrumentos aptos a restringir a liberdade e autonomia negocial privada, combatendo acirradamente os planejamentos tributários considerados abusivos. Com isso, pretendem coibir e evitar a elisão, ensejando a criação de uma norma geral antiabusiva.

Percebe-se que tal luta entre o Estado e o contribuinte, encontram-se, de um lado, os fundamentos do Estado Democrático de Direito, como a legalidade, a justiça, a igualdade, os respeito aos direitos e às garantias individuais, e de outro, os fundamentos do Estado Social, tais como a solidariedade, a igualdade e a capacidade contributiva.

Este conflito de valores leva ao entendimento de que, se por um lado o Fisco tem o poder-dever de fiscalizar e cobrar dos contribuintes seu real poder de contribuição, de outro, o art. $145, \S 1^{\circ}$, da Constituição Federal asseguram os direitos e garantias fundamentais dos cidadãos e da legalidade. Como são princípios constitucionais que estão em jogo, faz-se necessário uma ponderação desses valores para que se alcance um equilíbrio. A liberdade e a autonomia privada, quando limitada ou restringida deve ser expressa em lei, que estabeleça a forma, os procedimentos, as penalidades, tudo em razão da garantia do devido processo legal e do amplo direito a defesa.

O planejamento empresarial, como aduz Mary Elbe Queiroz (2012, p. 359), é: “a prática ou comportamento adotado para a boa gestão dos negócios, no sentido da autoorganização administrativo-financeira da empresa, com vista à obtenção da maximização de resultados (lucros)." Isto pode ser feito por meio de medidas que reduzam custos de mão de 
obra, custos administrativos e financeiros, o custo tributário. Somente com essa política empresarial e tributária, a empresa tem condições de obter um resultado mais favorável e prevenir-se de uma diminuição patrimonial, devido ao ônus fiscal imposto pela Administração Pública, e ver sua capacidade contributiva respeitada e obter vantagem competitiva no mercado. $\mathrm{O}$ planejamento tributário, por conseguinte, trata-se de um ato recomendável de gestão empresarial: tem conotação de orientação e recomendação estratégica e de ato ou negócio resultante do plano inicial, que se concretiza a partir do momento em que se materializa, pois assim é possível provar sua licitude ou se se trata de ato abusivo, ilícito, fraudulento ou simulado.

O planejamento tributário é realizado por meio de uma revisão fiscal, de acordo com Francisco Coutinho Chaves (2014, p. 6-7; 10) cujo profissional deve aplicar vários procedimentos, tais como, efetuar um levantamento histórico da empresa, identificando a origem de todas as transações efetuadas, e escolher a ação menos onerosa para os fatos futuros; verificar todos os fatos geradores dos tributos pagos e analisar se houve cobrança indevida ou recolhimento a maior; verificar se houve ação fiscal sobre fatos geradores decaídos, uma vez que os créditos constituídos após cinco anos são considerados indevidos; analisar, anualmente, qual a melhor forma de tributação do Imposto de Renda e da contribuição sobre o lucro, calculando de que forma (real ou presumida) a empresa pagará menos tributos; levantar o montante dos tributos pagos nos últimos cinco anos, a fim de identificar se há créditos fiscais não aproveitados pela empresa; analisar se há casos de incentivos fiscais existentes, tais como isenções, redução de alíquotas etc.; analisar qual a melhor forma de aproveitamento dos créditos existentes, quer por compensação ou por restituição.

Diante das figuras elisão fiscal, evasão fiscal, fraude à lei, simulação, dissimulação, abuso de direito e abuso de fato, compondo a problemática da licitude ou ilicitude do planejamento tributário, tanto no ordenamento jurídico estrangeiro, quanto o brasileiro, adotamse alguns critérios para averiguar tal discussão. O critério do propósito negocial é uma das formas de se identificar se o ato ou negócio é realizado conforme verdadeiro propósito negocial, isto é, se tem motivo econômico, empresarial, patrimonial, familiar, que sejam válidos e diferentes do que o objetivo de economizar tributos. A falta de propósito negocial é uma maneira de se averiguar se o planejamento tributário é lícito.

O ato ou negócio deverá ser submetido a um teste da presença de propósito negocial (business purpose test nos EUA), ou no exame de motivos econômicos válidos que o justificaram. "O business purpose test nada mais é do que uma razão comercial legítima tal como pode vir a ser demonstrada pelo sujeito passivo, em particular no caso de este ter adoptado uma via pouco habitual. O caráter pouco vulgar da via escolhida não constitui, contudo, um modo inadequado para obter o resultado 
pretendido nem esta inadequação pode ser explicada pela vantagem fiscal que subjaz. Pelo contrário, estamos apenas perante uma possível forma nova e imaginativa de realizar uma operação, que se pode explicar por razões fiscais." (SANCHES apud QUEIROZ, Mary Elbe. O planejamento tributário: procedimentos lícitos, o abuso, a fraude e a simulação. In: GRUPENMACHER; CAVALCANTE; RIBEIRO; QUEIROZ (org.) Novos horizontes da tributação: um diálogo lusobrasileiro. Cadernos IDEFF Internacional. Coimbra: Almedina, 2012, p.384)

Vale ressaltar que a intenção do contribuinte não pode ser utilizada como critério de avaliação de ato ou negócio: se se trata de negócio ou ato abusivo e com o intuito exclusivo de economizar tributo, com ocorre nos demais ordenamentos jurídicos.

A estrita legalidade tem sido mitigada em prol de outros valores, revelando um verdadeiro ativismo administrativo e jurisprudencial, sem embasamento legal e critério específico e uniforme, tanto no Brasil, quanto no exterior. Essa atitude de excessivo dirigismo estatal, que limita a liberdade e a autonomia privada tem levado a esses extremos de subjetivismo.

3. O sistema tributário é dotado de uma norma geral exclusiva no que tange à atividade de cobrar tributos: trata-se do princípio da estrita legalidade que realiza o primado da isonomia, ao discriminar contribuintes de forma igualitária por meio da lei e ao determinar que a lei seja aplicada da mesma maneira para todos os casos. (NACNAUGHTON, Charles William. Elisão e norma antielisiva. Completabilidade e sistema tributário. São Paulo: Noeses,2014, p. 497)

Neste ínterim, para a compreensão do assunto, importante elucidar alguns pontos sobre as normas antielisivas. Estas podem ser classificadas em preventivas ou repressivas, genéricas ou específicas.

A norma antielisiva preventiva genérica prescreve que a interpretação da norma tributária dever ser feita extensivamente, mesmo no caso do texto legislativo não induzir a essa postura hermenêutica ou que reduza a extensão da aplicabilidade de benefícios fiscais e a norma antielisiva preventiva genérica que se volta à regra-matriz de incidência tributária é considerada incompatível com o princípio da legalidade. Essas normas antielisivas preventivas genéricas sobre benefício fiscal devem determinar seus critérios, estabelecidos de forma clara, para que conceda previsibilidade ao contribuinte. Já, as normas antielisivas repressivas genéricas são consideradas inconstitucionais, uma vez que violam o princípio da estrita legalidade, da isonomia e têm o condão de autorizar, indevidamente, a invasão de competência de outro ente tributário. (NACNAUGHTON, Charles William. Elisão e norma antielisiva. Completabilidade e sistema tributário. São Paulo: Noeses, 2014, p. 500)

“As normas antielisivas preventivas específicas implicam em medidas que importem a máxima extensão de competência tributária possível e a eliminação de diferenças 
legislativas que permitam a elisão ou a instituição de benefícios fiscais restritivos com finalidades previamente definidas." (NACNAUGHTON, Charles William. Elisão e norma antielisiva. Completabilidade e sistema tributário. São Paulo: Noeses, 2014, p. 499)

18. Grande parte das decisões administrativas expedidas pelo Conselho Administrativo de Recursos Fiscais tidas como antielisivas ou impeditivas de atos sem propósito extratributário examinaram atos praticados com simulação ou sem causa jurídica. (NACNAUGHTON, Charles William. Elisão e norma antielisiva. Completabilidade e sistema tributário. São Paulo: Noeses, 2014, p. 499)

As normas antielisivas repressivas genéricas dispõem competência tributária à administração pública para que ela altere, de forma inaugural no sistema, os critérios da regramatriz de incidência a fim de possibilitar a tributação do valor economizado mediante a elisão tributária.

$\mathrm{O}$ art. 116, parágrafo único, do CTN, instituído pela Lei Complementar no 104/2001, somente ratificou o disposto no art. 149, VII, do CTN, uma vez que este já prelecionava a desconsideração do negócio jurídico dissimulado, portanto, de conformidade com Paulo de Barros Carvalho (2014, p. 83), este artigo não veio com escopo de alterar o ordenamento jurídico, impedindo a optimização fiscal das empresas, em razão do cumprimento do princípio da livre iniciativa. O contribuinte é livre para escolher qual ato ou atos negociais pretende praticar, tendo, como consequência, o nascimento ou não de uma obrigação tributária.

Na visão de Eduardo Marcial Ferreira Jardim (2011, p. 496-497), o parágrafo único do art. 116, do CTN não é inconstitucional. É uma norma vedatória da simulação fiscal e só seria considerado inconstitucional se fosse interpretado pela Administração Pública, como um dispositivo ampliativo de cláusula geral de norma antielisiva. Ao contrário, ele só abarca a figura jurídica da simulação fiscal, reiterando o acato à tipicidade tributária, uma vez que esta norma declara ineficácia apenas de ato simulado e nada mais, pois incide em fatos típicos de atos dissimulados, em razão da verdade material.

Segundo Charles William Nacnaughton (2014, p. 483), a Lei Complementar $n^{\circ}$ 104/01, que instituiu o parágrafo único do art. 116, do CTN veiculou uma norma antievasiva, porque, esse dispositivo reafirma a vertente de que existem normas antievasivas que conferem instrumentos para que o Fisco identifique as condutas evasivas dos contribuintes, ou seja, ele serve como mecanismo que requalifica ou desqualifica os atos jurídicos praticados relatados em linguagem pelos contribuintes, quando não existem elementos genéricos existenciais ou elementos categoriais que qualificam os negócios como tais ou quais. 
Como defensor da ideia de que o parágrafo único do art. 116, do CTN seja veiculador de norma antielisiva, há o jurista Ricardo Lobo Torres, citado pelo autor acima mencionado (2014, p. 483-485), que argumenta que o CTN já contava com mecanismos antievasivos, sendo desnecessária a instituição de mais uma norma por lei complementar; o Projeto de Lei Complementar $n^{\circ} 77 / 99$, em sua exposição de motivos já explana que o dispositivo tem por objetivo coibir abuso de formas jurídicas; o modelo do dispositivo é conexo à redação da legislação francesa, que é uma norma antielisiva; nenhum país democrático declarou inconstitucional, normas antielisivas; há conotação fortemente ideológica nas teses da legalidade estrita e na tipicidade fechada, sendo que esses princípios são filiados ao positivismo formalista e conceptualista.

Destarte, na visão de Charles William Nacnaughton (2014, p. 485), o legislador buscou combater a elisão abusiva, conforme se depreende da análise dos três primeiros argumentos de Ricardo Lobo Torres, porque, a um: uma lei complementar, a que instituiu o parágrafo único do art. 116, do CTN é de difícil aprovação e não se pode considerar que ela determinou a vontade do legislador; a dois, porque o texto é o aspecto objetivo da norma, é o elemento intersubjetivo capaz de legitimar o direito como um produto social. Portanto, ao enunciar palavras conservadoras como "dissimulação do fato gerador" no lugar de "ausência de propósito negocial" ou "abuso de forma jurídica", mesmo que a exposição de motivos tenha objetivado restringir a elisão, é mais fácil a aprovação de tal enunciado. O fato é que o aspecto vinculante é o texto e não a sua exposição de motivos, sendo que os parlamentares provavelmente tenham feito um balanço entre a exposição de motivos do legislador (intenção do relator do projeto) e o aspecto vinculante do texto, de forma que se chegou à conclusão de que seria mais aceitável uma norma que coibisse a dissimulação do evento tributável. Isso é mais fácil de ser aceitável numa eventual discussão, por atenuar sua força retórica. Continuando sobre a conclusão que o autor (2014, p. 496) chegou sobre o parágrafo único do art. 116, do CTN, este trata-se de uma norma antievasiva, em nome do princípio da estrita legalidade em matéria fiscal. Ele tem o escopo de conceder concretude à legalidade, à capacidade contributiva e à isonomia, que, juntos, concedem justiça e segurança.

12. A evasão tributária pressupõe a constituição de norma individual e concreta pelo contribuinte não compatível com a linguagem das provas, omitindo-se de se constituir a obrigação que seria devida em conformidade com a teoria das provas. (NACNAUGHTON, Charles William. Elisão e norma antielisiva. Completabilidade e sistema tributário. São Paulo: Noeses, 2014, p. 498) 
Voltando ao assunto da doutrina do propósito negocial ou "business purpose doctrine", esta surgiu no ordenamento jurídico norte-americano, assim como as doutrinas "substance over form doctrine" e "step transaction doctrine". Elas são normas que visam ser aplicadas de acordo com seus requisitos, e não estão relacionadas imediatamente com a solidariedade fiscal, com a isonomia ou com a capacidade contributiva. Não se tratam de coibir a elisão, nem estão relacionadas com o dever fundamental de pagar tributos. Elas foram criadas partindo da interpretação de normas tributárias específicas.

A doutrina denominada step transaction doctrine é interpretada pelos tribunais norte- americanos da seguinte forma: interpretam-se os eventos tributários para que sejam subsumidos ao que é previsto pelas normas fiscais.

\begin{abstract}
Tenhamos, inicialmente, a substance over form doctrine, que foi sendo construída no início do século XX pela Suprema Corte Norte-Americana.. Os fundamentos da referida Corte, para constituição dessa teoria, como se nota no famoso precedente Gregory x. Helvering, datada de 1935, é atingir a finalidade "da lei" e revelar os "verdadeiros fatos" envolvidos em cada transação. (NACNAUGHTON, Charles William. Elisão $e$ norma antielisiva. Completabilidade e sistema tributário. São Paulo: Noeses, 2014, p. 400-401)
\end{abstract}

O propósito negocial parte do pressuposto de que a reestruturação societária adotada pelo contribuinte, que seja isenta de Imposto de Renda, precisa ser pautado em plano negocial e não como apenas um mecanismo para afastar a tributação. Em decisão acerca do precedente Gregory x. Helvering, teve como fundamento o alcance de um benefício fiscal específico. Não se baseou tal decisão em pressuposto genérico de que o planejamento tributário seja ilícito quando realizado para fins de economia tributária.

\begin{abstract}
Voltando-nos, um pouco à ideia de "substance over form doctrine", diríamos que assim como Charges S. Pierce sustenta que os significados dos signos estão diretamente associados a como esses signos interferem em nossas condutas", o direito comum norte-americano construiu a noção de que a realização de atos jurídicos conotados pelas normas fiscais pressupõe a irradiação de certos efeitos. Sem a verificação concreta desses efeitos no plano concreto, tais atos se reputam juridicizados, para fins tributários, ainda que documentalmente constituídos. Interessante notar como essa dicção é oposta a veiculada pelo artigo 118, inciso II, do Código Tributário Nacional, que afasta a necessidade de efeitos de certas situações para fins de qualificação do evento tributário, [...] (NACNAUGHTON, Charles William. Elisão e norma antielisiva. Completabilidade e sistema tributário. São Paulo: Noeses, 2014, p.403)
\end{abstract}

De acordo com a Suprema Corte dos Estados Unidos da América, baseada na interpretação da legislação fiscal onde se preleciona que as perdas devem ter real amparo 
econômico, decidiu em precedentes como Frank Lyon Co. v. United States, que tratou de instituição de um leasing, para, posteriormente convertê-lo em compra, que esse procedimento não seria considerado equivalente para fins fiscais, a um financiamento; e no caso Posey $v$. United States, que o fato de ter a disponibilidade econômica de renda, por si só, já se considera passível de tributação. Isso demonstra que outros segmentos jurídicos não se confundem com essa interpretação da lei tributária.

Ao enunciar que a disposição econômica de renda já é disponibilidade para fins de incidência do Imposto sobre a Renda, a doutrina da substância sobre a forma está, em última análise, determinando qual a hipótese de incidência desse tributo - aliás de forma equivalente ao que ocorre no Brasil que acata a disponibilidade econômica da renda. (NACNAUGHTON, Charles William. Elisão e norma antielisiva. Completabilidade e sistema tributário. São Paulo: Noeses, 2014, p. 404-405)

A Suprema Corte Norte-Americana decidiu que a teoria substance over form doctrine não pode ser aplicada quando a legislação tributária pressupor um conceito que seja menos dissociado de comportamentos concretos, para efeito tributário, e mais atrelado aos signos empregados nos documentos pelos contribuintes.

Daí por que, a Suprema Corte Norte-Americana já se manifestou no sentido de
que a substance over form doctrine não seria aplicável quando a legislação
tributária pressupõe um conceito que, para fins de tributação, é menos dissociado
dos comportamentos concretos e mais apegado aos signos utilizados nos
documentos pelos contribuintes. Isso foi pressuposto pela referida Corte no
precedente "Kenetchs $v$. United States". (NACNAUGHTON, Charles William.
Elisão e norma antielisiva. Completabilidade e sistema tributário. São Paulo:
Noeses, 2014, p. 404-405)

As teorias "substance over form doctrine" e "business purpose doctrine" não são iguais, contudo estão intrinsecamente relacionadas. Para a primeira teoria, o que importa são os fatos envoltos na operação, sendo irrelevantes os motivos porque os contribuintes as realizam.

\begin{abstract}
A exemplo da substância sobre a forma, a business purpose doctrine também tem base na interpretação de normas jurídicas tributárias. A legitimação dessa teoria originou-se pela fundamentação de que certos benefícios fiscais, no direito norteamericano, pressupõem que o contribuinte aja com propósitos extratributários, para que esses benefícios sejam aplicados. (NACNAUGHTON, Charles William. Elisão e norma antielisiva. Completabilidade e sistema tributário. São Paulo: Noeses, 2014, p. 405)
\end{abstract}

As doutrinas substance over form doctrine e a business purpose doctrine são distintas, conforme explana Charles William Cacnaughton (2014, p. 406). A primeira preleciona a presunção de que os atos devem ser interpretados conforme o padrão denominado 
objeto dos signos, salvo disposição expressa na lei, A doutrina do propósito negocial preleciona a legitimidade da finalidade inerente a certo benefício fiscal que o contribuinte deve observar.

A doutrina do propósito negocial é muito criticada nos Estados Unidos, porque é carente de objetividade e imprevisibilidade, principalmente, quando aplicada pelos tribunais inferiores, porque, os magistrados questionam a finalidade dos benefícios fiscais que nem sempre são exteriorizados, e, consequente, atribuem a eles, finalidades imprevisíveis, para afastar o planejamento tributário.

Por esse motivo, em 2010, a doutrina do propósito negocial foi positivado no "Health Care and Education Reconciliation Act of 2010". Esse ato determinou que uma operação, para passar no teste da "substância econômica" deve apresentar uma substancial modificação na posição econômica da parte e um propósito substancial na operação.

\begin{abstract}
Assim, nota-se que na ordem de evolução das coisas no referido país, não basta o propósito negocial para que a operação seja aceita, é preciso uma combinação na posição econômica da parte. Essa alteração, contudo, é recente ainda sem reflexos consideráveis nas decisões dos tribunais. De qualquer sorte, propósito negocial e a doutrina da prevalência sobre a forma passam a ser instâncias aplicáveis ao modo de se interpretar a legislação do Imposto sobre a Renda. (NACNAUGHTON, Charles William. Elisão $e$ norma antielisiva. Completabilidade e sistema tributário. São Paulo: Noeses, 2014, p. 408)
\end{abstract}

Por fim, após exame dos julgados e casos envolvidos pelas presentes doutrinas, os professores dos Estados Unidos concluíram que os fatores estatisticamente relevantes para que determinem se uma operação é realizada por meio de um planejamento tributário abusivo são: a operação será considerada abusiva quando seu julgamento ocorrer em época em que o Estado precisa ou não de recursos, caso contrário, não; se o réu da ação for o Fisco, a operação, geralmente é considerada não abusiva, mas, se o réu for o contribuinte, normalmente a operação por ele feita será considerada abusiva; quando o contribuinte solicita restituição de tributos, esta operação terá forte chance de ser considerada abusiva; outro fator que determina haver planejamento tributário abusivo ou não é a composição da Suprema Corte. (BLANCK apud (NACNAUGHTON, Charles William. Elisão e norma antielisiva. Completabilidade e sistema tributário. São Paulo: Noeses, 2014, p. 413-414)

No Brasil, os doutrinadores, magistrados e advogados preocupam-se em conectar os institutos de "substância sobre a forma", "necessidade de propósito negocial" e "step transaction doctrine" à lei e institutos do direito positivo, especialmente tributários. Da mesma forma, grande parte dos arestos do Conselho Administrativo de Recursos Fiscais e do antigo Conselho de Contribuintes do Ministério da Fazenda que aplicam instâncias tidas como 
antielisivas, também buscam guarida na legalidade, de maneira que pode-se dizer que atuam como instâncias que objetivam coibir a evasão tributária e não propriamente a elisão.

Sem embargo, não ignoro que esses mesmos recursos legitimadores de desqualificação ou requalificação de atos jurídicos também podem, e vêm sendo utilizados, como instrumentos para neutralizar operações praticadas com elisão tributária. Mas, é preciso diferençar esses dois casos de aplicação desses institutos, seja para uma meditação mais profunda do que se opera na pragmática jurídico-tributária, no que que diz respeito à elisão, seja por que há uma espécie de "verdade" que sustenta que o Conselho Administrativo de Recursos Fiscais CARF não mais permite a prática de atos com fim exclusivo de economia de tributos. (NACNAUGHTON, Charles William. Elisão e norma antielisiva. Completabilidade e sistema tributário. São Paulo: Noeses, 2014, p. 415)

Percebe-se que no Brasil, não se permite a prática de atos ou negócios jurídicos com o único objetivo de economizar tributos, o que se evidencia pelo questionamento pelos tribunais e a Administração Pública acerca da necessidade de propósito negocial quando da prática de atos ou negócios jurídicos. Faz-se mister, no entanto, diferençar o propósito negocial que coíbe a evasão fiscal, do propósito negocial que visa neutralizar a elisão tributária, porque, muito embora tenham a mesma terminologia, apresentam efeitos jurídicos distintos.

Elbe Mary Queiroz propõe que a limitação à liberdade e à autonomia privada, quanto ao direito tributário seja submetida a regras e que aconteça de maneira proporcional, por meio de critérios e limites estabelecidos em lei, a fim de evitar que haja abuso e violações aos direitos dos contribuintes. Por isso ela propõe a adoção do critério do propósito negocial para averiguar se os atos ou negócios efetuados por planejamento tributário sejam considerados lícitos e não abusivos. Se não houver um propósito negocial, tal planejamento tributário será considerado ilícito e abusivo.

“O critério proposto, a partir do qual os planejamentos lícitos poderão ser considerados como abusivos, é a falta de propósito negocial ou a ausência de motivo extratributário para que seja realizado um ato ou negócio.” (QUEIROZ, Mary Elbe. O planejamento tributário: procedimentos lícitos, o abuso, a fraude e a simulação. In: GRUPENMACHER; CAVALCANTE; RIBEIRO; QUEIROZ (org.) Novos horizontes da tributação: um diálogo luso-brasileiro. Cadernos IDEFF Internacional. Coimbra: Almedina, 2012, p. 387-388)

Vale mencionar a questão da duplicidade de tributação sobre um mesmo fato jurídico, pois toda requalificação de atos ou negócios dos contribuintes pode gerar efeitos em outras relações jurídicas por ela desencadeadas, configurando, destarte, um confisco, e desrespeito ao princípio da capacidade contributiva do contribuinte. 


\begin{abstract}
No campo específico das penalidades, a diretriz suprema da segurança jurídica é violada quando da inserção, no ordenamento jurídico, de instrumentos normativos infralegais tipificando infrações e prevendo as sanções respectivas, bem como distorce o conteúdo de significação deste preceito supremo a hipótese de uma lei nova determinar que penalidadea mais graves possam retroagir, atingindo fatos pretéritos. (PADILHA, Maria Ângela Lopes Paulino. As sanções no direito tributário. São Paulo: Noeses, 2015, p. 103)
\end{abstract}

De acordo com Elbe Mary Queiroz (2012, p. 389): "Para cercar-se de maior segurança, o propósito negocial precisa ser demonstrado por meios probatórios documentais, como laudos e documentos técnicos provenientes de terceiros ou de empresas independentes, que reduzam a margem de incerteza sobre qual é o real objetivo que deu causa à realização do ato ou negócio." Por isso faz-se necessário a elaboração de laudo para demonstrar a existência de motivo extratributário para excluir a ilicitude. Esse laudo terá o condão de inverter o ônus da prova, de maneira que a autoridade fiscal terá de provar a ilegitimidade do propósito por meio de invalidade do laudo. Caso a autoridade fiscal não consiga invalidar o laudo, este afastará o tax alert. O laudo é, segundo Fabiana Del Padre Tomé (2011, p. 131), uma prova documental que ocupa lugar de destaque nos processos administrativos tributários. Eles precisam ser construídos com observância às regras impostas por esse sistema.

Segundo Elbe Mary Queiroz (2012, p. 393): “A proposta da NGAA de tipificar o propósito negocial como critério caracterizador do ato ou negócio abusivo tem por objetivo reduzir a incerteza e a insegurança que hoje dominam a relação entre Fisco e Contribuinte no Brasil."

Por conseguinte, essa alternativa pode ser a melhor elencada para reduzir as incertezas e a insegurança imperantes entre o contribuinte e o fisco no país, entretanto, poderia o legislador repensar o direito no país, a fim de reduzir o dirigismo estatal e por conseguinte, reduzir a alta carga tributária que assola o contribuinte brasileiro que impede o desenvolvimento nacional. Isso porque é inegável a desproporção da carga tributária exigida ao contribuinte em relação a atuação do Estado quanto a sua contraprestação ao cidadão. 


\section{CONCLUSÃO}

Os princípios constitucionais da livre iniciativa e da autonomia privada são uns dos que alicerçam a República Federativa do Brasil. A livre iniciativa é fundamental no Estado Democrático de Direito para que se cumpra o primado da ordem econômica brasileira. $\mathrm{O}$ princípio da liberdade de iniciativa é derivado da livre iniciativa e visa à conquista da justiça social.

O Estado Social, tendência mundial, caracterizado por um forte intervencionismo na vida do cidadão, no Brasil tem cobrado alto preço para se manter. Cada vez mais no Brasil, se exige uma alta carga tributária, que, caminha na contramão do direito do cidadão à livre iniciativa e à autonomia privada. Se por um lado o Fisco tem o poder-dever de fiscalizar e cobrar dos contribuintes seu real poder de contribuição, de outro, o art. 145, $\S 1^{\circ}$, da Constituição Federal asseguram os direitos e garantias fundamentais dos cidadãos e da legalidade. Como são princípios constitucionais que estão em jogo, faz-se necessário uma ponderação desses valores para que se alcance um equilíbrio. A liberdade e a autonomia privada, quando limitada ou restringida deve ser expressa em lei, que estabeleça a forma, os procedimentos, as penalidades, tudo em razão da garantia do devido processo legal e do amplo direito a defesa.

Cada dia que passa tem sido mais difícil empreender e sobreviver. Não é sem justificativa que o contribuinte tem lançado mão de mecanismos para angariar lucro e reduzir custos. Por isto o planejamento tributário se faz necessário neste contexto. Em contrapartida, o Fisco tem se utilizado de mecanismos para inibir o contribuinte que agir com o intuito de dissimular ou simular algum ato ou negócio jurídico, para economizar tributo ou mesmo deixar de ser cobrado, por mascarar a configuração da formação do crédito tributário, pois tal atitude será considerada ilícita. Outrossim, a fraude à lei e o abuso são outras figuras ilícitas.

Os legisladores brasileiros tendem a basear-se em ordenamentos jurídicos alienígenas, como no caso, as teorias "substância sobre a forma", "necessidade de propósito negocial" e "step transaction doctrine", para se adequar ao direito privado e tributário. A teoria do propósito negocial tem sido muito empregada para justificar a aceitação dos planejamentos tributários, em nome da legalidade, da capacidade contributiva e da isonomia, tanto é que a autora Elbe Mary Queiroz sugere a instituição de uma Norma Geral Antiabuso (NGAA) com base nesta teoria. 
As normas antielisivas repressivas genéricas são consideradas inconstitucionais, porque violam o princípio da estrita legalidade, da isonomia e têm o condão de autorizar, indevidamente, a invasão de competência de outro ente tributário, enquanto que as normas antielisivas preventivas genéricas prescrevem que a interpretação da norma tributária deva ser feita extensivamente, mesmo no caso do texto legislativo não induzir a essa postura hermenêutica ou que reduza a extensão da aplicabilidade de benefícios fiscais e a norma antielisiva preventiva genérica que se volta à regra-matriz de incidência tributária é considerada incompatível com o princípio da legalidade.

As normas antielisivas preventivas específicas implicam em medidas que importem a máxima extensão de competência tributária possível e a eliminação de diferenças legislativas que permitam a elisão ou a instituição de benefícios fiscais restritivos com finalidades previamente definidas.

No que tange à interpretação do art. 116, parágrafo único, do CTN, instituído pela Lei Complementar $n^{\circ}$ 104/2001, ele somente ratificou o disposto no art. 149, VII, do CTN, porque este já ensejava a desconsideração do negócio jurídico dissimulado, portanto, este artigo não tem o condão de alterar o ordenamento jurídico, impedindo a optimização fiscal das empresas, para não ferir o princípio da livre iniciativa. O contribuinte é livre para escolher qual ato ou atos negociais pretende praticar, tendo, como consequência, o nascimento ou não de uma obrigação tributária. O autor Charles William Nacnaughton considera esse artigo, uma norma antievasiva, em nome do princípio da estrita legalidade em matéria fiscal, pois tem o escopo de conceder concretude à legalidade, à capacidade contributiva e à isonomia, que, juntos, concedem justiça e segurança.

O contribuinte tem o direito e o dever de buscar formas menos onerosas para empreender e viver. A busca de recursos que melhorem as gestões econômica e tributária, tanto da pessoa física quanto da jurídica, desde que sejam de acordo com o ordenamento jurídico pátrio são lícitos, e, por conseguinte, o planejamento tributário que não vise somente a economia de tributos, mas que seja efetuado por meio de atos e negócios jurídicos lícitos, sem desvio de finalidade, tanto em relação seus significados no direito privado, quanto no direito tributário, devem ser aceitos pelas autoridades administrativas e o Judiciário, porque se tratam de elisão fiscal. Isso ratifica a máxima dos princípios ontológicos do direito, como a expressão "tudo que não estiver juridicamente proibido, estará juridicamente permitido", princípio determinante do regime jurídico privado, em detrimento da expressão: “tudo que não estiver 
juridicamente permitido, estará juridicamente proibido", princípio determinante do sistema normativo público. 


\section{REFERÊNCIAS}

CARRAZZA, Roque Antonio. Curso de direito constitucional tributário. 26. ed. São Paulo: Malheiros, 2010.

CARVALHO, Paulo de Barros. Curso de direito tributário. 25. ed. São Paulo: Saraiva, 2013.

CARVALHO, Paulo de Barros. Derivação e positivação no direito tributário. 2. ed. Livro I. São Paulo: Noeses, 2014.

CHAVES, Francisco Coutinho. Planejamento tributário na prática. Gestão tributária aplicada. 3. ed. São Paulo: Atlas, 2014.

DE PAULA, Lucimar. A problemática da aplicação do princípio da autonomia privada nas relações contratuais contemporâneas. In: NALIN, Paulo. Contrato \& Sociedade. Princípios de Direito Contratual. v. I, Curitiba: Juruá, 2008.

GOMES, Orlando. Contratos. 25. ed. Rio de Janeiro: Forense, 2002.

GÓMEZ, J. Miguel Lobato. Livre-iniciativa, autonomia privada e liberdade de contratar. In: NALIN, Paulo Roberto Ribeiro (coord.). Contrato \& Sociedade: A autonomia privada na legalidade constitucional. v. II. Curitiba: Juruá, 2006.

JARDIM, Eduardo Marcial Ferreira. Dicionário de direito tributário. São Paulo: Noeses, 2011.

NACNAUGHTON, Charles William. Elisão e norma antielisiva. Completabilidade e sistema tributário. São Paulo: Noeses, 2014.

NALIN, Paulo. A autonomia privada na legalidade constitucional. In: NALIN, Paulo (coord.). Contrato \& Sociedade. A autonomia privada na legalidade constitucional. Curitiba: Juruá, 2006.

PADILHA, Maria Ângela Lopes Paulino. As sanções no direito tributário. São Paulo: Noeses, 2015.

QUEIROZ, Mary Elbe. O planejamento tributário: procedimentos lícitos, o abuso, a fraude e a simulação. In: GRUPENMACHER; CAVALCANTE; RIBEIRO; QUEIROZ (org.) Novos horizontes da tributação: um diálogo luso-brasileiro. Cadernos IDEFF Internacional.

Coimbra: Almedina, 2012.

TOMÉ, Fabiana Del Padre. A prova no direito tributário. 3. ed. São Paulo: Noeses, 2011. TORRES, Andreza Cristina Baggio. Direito civil-constitucional: a função social do contrato e a boa-fé objetiva como limites à autonomia privada. In: NALIN, Paulo (coord.). Contrato \& Sociedade. A autonomia privada na legalidade constitucional. Curitiba: Juruá, 2006.

SZTAJN, Rachel. Teoria jurídica da empresa. Atividade empresária e mercados. 2. ed. São Paulo: Atlas, 2010. 
ZANOTI, Luiz Antonio Ramalho. Empresa na ordem econômica social. Princípios e função social. Curitiba: Juruá, 2009. 